\title{
Avesta における風と馬 \\ Horses and Wind in the Avesta
}

岡 田 明 憲 OKADA Akinori

\begin{abstract}
The myths of the people of ancient Iran contain references of many animals and among them the horse is of particular importance. In mythological terms, the horse appears as the symbole of the warrior class. In the beliefs of the people of ancient Iran, the connection between the horse and the warrior was related to the ambiguity of the horse. In the Avesta, this is shown by the use of -aspa (horse) in proper names and in the opposition of the white horse and the black horse.

Studies in ethnology show that the horse is frequently connected with deities of the wind. It is not unusual, for example, for a horse to serve as a sacrifice to the deity of the wind. In the Avesta, too, passages hinting at the ties between horses and the wind can be found. In Zoroastrianism, wind possesses opposing qualities. Vayu, the god of wind, presents a clear duality. The twin Mainyus of good and evil reside in Vayu, like Zurvan.

Wind is the demarcation between life and death, situated between this world and the after life, as demonstrated in the Hāōoxt Nask and the Aogamadaécā. The horse, too, represents the character of being this boundary or being situated in the between. This point can be seen in the horse as a metamorphosis of Verethraghna as well as the Gushnasp fire venerated during the Sassanian dyansty. The proof for the tie with the boundary is the prayer on horseback frequently mentioned in the Avesta.
\end{abstract}

\section{I. 馬・太陽・雨}

イラン人が属する印欧語族にとり，馬が重要な役割を担っていた事実は，すでに何度 も指摘されてきたことであり，ヘロドトス等の古典作家の記述に照らしても，ペルシア 人やスキタイ人が馬を大切にしていたのは確実である。『アヴェスタ』の文中にも，馬 に関する記事が見られ，馬が古代イランの代表的な家畜であったことが判る。『アヴェ

* 本学会会員

Member of the Society for Near Eastern Studies in Japan 
スタ』では, 水中, 地中, 空中, 地表を駆ける, 草を食む, 5 種の動物を説き, それを ahura 的なものと daēva 的なもの,すなわち善・悪のカテゴリーに大別する。そし て, この ahura 的なものに属するのが家畜であり, さらに家畜は, 大家畜 staora- と 小家畜 pasav-に分けられる。そこで，馬は牛ととるにこの大家を畜を代表している。

ゾロアスター教では，伝統的に牛が特別な意義を有していた。それは，ゾロアスター 自身が Gā $9 \bar{a}$ の冒頭で, 牛の魂 gə̄uš urvan-を登場させていることに象徴される。 パールシーたらの解釈では, この牛は大地の生命, そして全ての被造物の生命を代表す るものとされる。この牛の象徵的意義は, パフラヴィ一文献等で述べられる, ゾロアス ター教の創造神話に適ったものであり,さらにミトラス教の密儀解釈にも通じるもので ある。すなわち Bundahišn では, アフレマン（ガナーグ・メーノーグ）の犠牲となっ た原牛から，種々の植物と動物が生じたことが説かれる。またミトラス教の屠牛が，再 生・復活の儀礼であった事は, 一般に認められている事実である。

牛の象徵的意義に注目するパールシーたちの伝統は, それに反して, 馬についてはほ とんど語らない。これは彼等が，牛を特別視するとンドゥー社会との親密な関係を主張 したいだけの理由で, そうしたのではない。パールシーは, 八オマの使用や太陽崇拝等 を別にすれば, ゾロアスターの思想に忠実であろうとする傾向が見られ, 彼等の牛の重 視や馬の軽視は，この面からも首肯できるからである。何故なら牛は，ゾロアスターの 直説である「ガーサー」で言及される，一種の聖獣である。これに対し馬は，乙ばしば 前ゾロアスター的, さらには反ゾロアスター的なるのを含む, Yašt の内容に主に係っ ているからである。

現存する Yašt の中には, その名称からして, 特に馬と結びつく Drvāsp Yašt が 存在する。しかし, この Yašt の実質的内容は, 畜獣に健康を賦与する女神への讃歌 であって，馬の意義そのものを物語るものではない。一方，Yašt 全体を通じて見られ る特色として，馬と戦士との結びつきが注目される。それ故に古代イランの場合におい ても, Dumezil 流に三機能説をもって，馬の意義を説明する解釈が主張されるわけであ る。この馬と戦士の結びつきについては, 近年のイラン学の集大成とも言えるEncy. clopedia Iranica の ASB の項でも述べられており, 考古学的にも否定できぬ事実であ る。しかし，この事実が如何なる意義を有するかといらことは，自と別の問題であり， この点に関しては, 本論文で後に述べる。

Drvāspā の他にも, 『アヴェスタ』中の神格にあって, 馬と密接なものに Mi

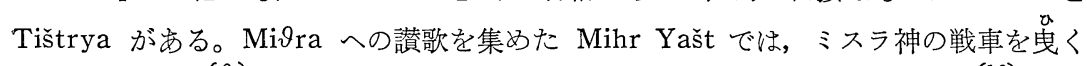
白馬について述べ，またこの神を aurušāspa-（白馬を有するの）と称している。この 背景には，古代オリエント世界に护将馬，特に白馬と，太陽神との関係がある。クセ 
ノポンは太陽神 (ヘーリオス) の神馬の事を記しているじ の王が太陽に捧げた馬についての記事がある。一方でへロドトスは, スキタイ系のマッ サゲタイ人が，太陽神を崇拝して犠牲に馬を供えたことを述べている。さらに, ヴェー ダ神話における太陽神スーリアと馬との関係なども考慮すれば，この種の信仰が印欧語 族的なものだったとも言える。つまり，『アヴェスタ』のミスラの場合も，太陽神的な 性格を有するものとして，馬と関係しているのである。

Tištr Yašt は, Tištrya が白馬に変身し, 黒馬の姿をした Apaoša (旱鬼の悪魔) と闘争すると述べる。この場合ティシュトリヤは雨神と考えられている訳で, そこで彼 が敵に勝利したことにより，水は阻止するものなき奔流となって世界に注ぐと説かれる。 中央アジアに拉いては，このティシュトリヤ神話に起源を有すと見られる，雨神と馬の 密接な関係を証す遺物が発見されている。ティシュトリヤが雨神とされるのは, 元来は 彼がシリウス星を神格化したものであり，古代エジプトに拉るる，この星の出現とナイ ルの氾濫との関係に結びっくものとする説が有力である。しかし，インド・イラン的に も, ヴェーダ祭式で雨乞いに馬を用いる例がある。さらに水と馬の関係が普遍的なこと は，民族学の成果によって明らかである。

\section{II. 風神と馬}

日本には古くから，馬を風神と同一視したり，風神に馬を犠牲として捧げる風習があ ったとされる。またヨーロッパでる, 風のイメージとして馬が用いられることを, ニン グの象徵解釈が明らかにしている。さらにチベットに和いても，「風の馬」を意味する rlung-rta，すなわら prayer-flag の風習がある。この rlung-rta については，中国の竜 馬 long-ma に起源があるとする見解もある。しかし，それを専ら風に㢕かすことによ って，生命力を充進させることに意義があるのであるから，イラン的な騎士のリボン (鉢巻) と同類のものと考皇る゙さざある。ちなみにチベットの文化には，インドや中 国の影響だけでなく、イラン的なものの有ることがすでに指摘されている。

イラン文化の強い影響下にあったクシャーン朝でも，風神の信仰があった。そこでは, ゾロアスター教の Vāta やV Vayu に起源を有する, ウァドーやウェーショーの銘文を もつコインが発見されている。一方で, クシャーン朝の時代は, サウラと称するインド の太陽崇拝が始った時期でもある。として，そこに拈ける太陽神の表現は，帯を締め長 鞉をはくなどと図像学的に規定されるが，これは騎馬戦士の風俗に倣ったものである。 そこで, 風神信仰も, クシャーン朝に和ける騎馬戦士の風俗と, 何らかの関係が有って も不思議でない。以上の点を考吕合すと，『アヴェスタ』での風神と馬の関係が当然問 題にされていいわけだが，従来この点に部する研究は甚だ乏しい。確かに現存の『アヴ 
エスタ』本文中で, 明確に両者の関係を述べている部分が見出し難いといら事実は，こ の様な研究を困難なものにする。しかしとれでも，両者の関係を暗示する個所はある。

風神の讃歌である Rām Yašt では, ワユの別名として，あるいはとのエピセットと して, aurva-なる語が用いられている。aurva-は, aurvant-と同じく「駿足なる」 意で，馬の性質に関連する語である。駿足の馬を有することが，しばしば英雄と同義と され，ウィーシュタースパの父の名は aurvat. aspa-である。この速きことを以てす る，風と馬の連想は，『アヴェスタ』の他の個所にも見られる。例觉ば，スラオシャの 䊁獣は，「馬よりも速く，風よりも速い」と述べられる。この種の連想はインドにおい ても存在し，『マハーバーラタ』では，ワユに相当するvāyu が馬に比べられている。 中世ペルシア語文献では，風神 wāy i weh が「騎士の装束」 brahma i artēštārīh を 着ることで, この事を暗示している。

以上のように，風と馬の関連を直接証拠立てる文や語を，関連資料中に見出すことも 不可能ではない。しかしそれよりも，ゾロアスター教における風や馬そのものの性格を 考察することによって，両者の密接な関係が明らかになる可能性がある。それは，両者 が共に有する両義的性格に注目することである。それにより新たな視点が開けるばかり か，さらにとのことを通して，ミスラや戦士と馬との関係にも，これまで見逃されてい た意義付孖ができることも考えられる。先ずワユが両義的性格を有するものであること は，「ラーム・ヤシュト」に次の文があることで明らかである。

実に，私の名は風である。義者ザラスシュトラよ。

私の名が風（ワユ）である所以は，両方の被造物を追いかける（ワーイ）からであ る,

すなわち，スプンタ・マンユの創ったものと, アンラ・マンニの創ったもの（の両 者) を。

私の名は追い着く者である，義者ザラスシュトラよ， 私の名が追い着く者である所以は，両方の被造物に追い着くからである， すなわち，スプンタ・マンニの創ったものと、アンラ・マンニの創ったもの（の両 者) 飞。

私の名は全てを征服する者である，義者ザラスシュトラよ， 私の名が全てを征服する者である所以は，両方の被造物を征服するからである， すなわち，スプンタ・マンニの創ったものと、アンラ・マンユの創ったもの（の両 者)を。 
ここに風（ワュ）は，善なるスプンタと，悪なるアンラの両マンユに関係するもので ある事実がわかる。それ故，ゾロアスター教徒は，この風の相反する性格を分離し，善 なる部分，すなわちスプンタ・マンユに属する風のみを祭るべきとした。中世ペルシア 語文献では，善き風 wāy i weh と悪しき風 wāy i wattarを区別している。として 後の神学でも, 神 (ヤザタ) としての善き風と, 悪魔(ダエーワ)である悪しき風を考 学ている。

\section{III. 風とズルワン}

風が善・悪の両義的性格を有するとされるのは，それが炎熱を除いたり，作物を実ら す雨をもたらす半面，時には暴風となって災害を生じさせるからである。そして，しば しば特定の方角から吹く風が，この相反する結果に結びついた。『リグ・ヴェーダ』で も，相異なる方角から吹く二種の風について述べている。しかしそこでは，未だ明確に それを，善・悪の性格に区別していない。ところが『アヴェスタ』は，南風を善とし， 北風を悪とする。前者は芳香ある風であり, 後者は悪臭の風である。北風は古代イラン 人の嫌った寒風に関係して拈り，そこに気象上の事実が反映しているのは確かである。 しかし単にそれだけでなく，この南風と北風との対立には，神話的背景が存在する。

神話的思考に执いては，近代人の場合と異って，空間を同質的な認識範隯とのみ考光 ることなく，全ての存在物と同様に，質的な価值を有するものとして分類する傾向があ る。古代イラン人の場合は，そこにゾロアスター教的二元論を導入し，南北に二分して， 一方を神に他方を悪魔に結びつけた。ゾロアスタ一教徒の礼拝は南面して行われるし， 浄めにより追放された魔物たちは北に逃げる。『アヴェスタ』では, 明確に北を地獄の 方角とし，ゾロアスターを誘惑しようとした悪魔アンラ・マンユが，北方から走り来っ

たと述べている。一方で，この二元論による空間の区分は，南北の水平方向だけでなく， 上下の垂直方向にもなされる。すなわち，神や天使の住む天上の光明界と，悪魔とその 配下が垫す地下の暗闇界である。

天国と地獄を垂直方向に位置付けるのは，シャーマニズム的な世界観に共通のもので あるが，そこでは天国と地獄の中間に人間の住む世界を想定する。つまり，世界を三つ の領域に分けるのである。二元論を基本とするゾロアスター教では，この第三の領域は， 善・悪両勢力の影響下にある不安定なものと考えられる。それは，こす㐫としては，神 と悪魔の戦場であり，㐫㐫としては，善・悪同等の者が赴くHamēstagān である。 さらに，宇宙論的にこの中間領域を想定し，アフラ・マズダーの光明界とアンラ・マン ユの暗黒界の両者を隔てる虚空が説かれる。『ブンダヒシュン』では，この虚空 tuhig を指して，人々が風 wāy と称すと述べている。さらにそこでは，善・悪の混合が生起 
するともされる。

ヴェーダの神話も，神々を天・空・地の三界に配す。そしてそこでは，風神である Vāyu，Vāta が，天地の中間 antarikṣa たる空界を代表する神格である。空界には他 に, Indra, Rudra, Marut 等が配されるが，何れも両義的性格を有す点は注意すべきで ある。Rudra は，吉祥とともに破壊の神である Śiva の起源である。Marut は暴風 雨神であり，その怒りが万物を恐怖させる半面，人々に恵みをもたらし医薬を施す。 Indra の両義性については, 『アヴェスタ』で彼が悪魔とされると同時に, 本来彼の別

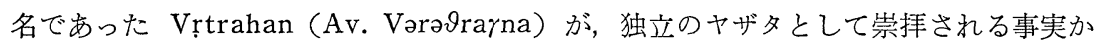
らも明らかである。

ゾロアスター教に损いて，両義性を代表するのが Zurvan である。それ故，ズルワニ ズムを，正統ゾロアスター教の二元論に反する，異端説であるとする解釈も存在する。 また Eznik によるアルィニア語史料は，ズルワン（Zrouan）をアフラ・マズダー（Ormizd) とアンラ・マンユ (Arhmn) を生んだ根元神であると述べる。ところで，この ズルワン，すなわち「時間」の意義を有するサンスクリットの kāla が，ワユを指する のとして用いられている例がある。すなわち Aogəmadaēcā 77 では，無慈悲なるワ ユ wāy anāmurzid を訳して, kālasya akșaminah としている。この「無慈悲なる ワニ」には，死者の魂を地獄に引きずり込むと信じられた悪魔 Astō.vī $\delta \bar{a} t u$ と同様な， 死神のイメージが予想されている。一方でズルワンも，死者の路を造るものであるから， ここに両者が結びっく理由が有った。

死神としてのワユは，風神の負の半面でしかない。しかしワユとズルワンの結びつき は，この種の反価值的な面のみに限られるわけでなく，それをも含めた，より全体的な 性格に関係している。すなわらズルワンにも，すでにワユ（風）に関して述べたと同様 に，相対する二者の中間に位置付けられるといった性格が見出せるのである。ゾロアス ター教の神学には, アフラ・マズダー (Ohrmazd) とアンラ・マンュ (Ahreman) の 遭遇に際して，両者の結しだ契約を設定したのがズルワンであるとする説がある。この 時の契約の内容は，9000年に及ぶ善・悪両霊の闘争（混交）と分離に関するものであっ た。一般に契約とは両者の間に存在するものであるから，そこにズルワンが登場するの は，彼の中間者的性格を物語る。そして中間者とは，換言すれば境に存在するものであ り，境にあるものは，その両側のものを分離すると同時に結びつける。ワユは空間的に この境を表わし，ズルワンは，時間的にその働きを示すのである。

\section{IV . 死者との関係}

ワユの一面が無慈悲な死神であることはすでに述べだ。ところが, この風神は, 同時 
に死者の魂を守護する者であるとも説かれている。すなわち『アオグマダエーチャー』 では, 善きワユ wāy i weh が死後 4 日目の暁に, スラオシャ Srōš, ラシュヌ Rašn, アルシュタートAštād, ミスラ Mihr や, 義者のフラワシ Frawahr とともに, 死者の 魂を出迎えると述べる。彼等は, 死者の魂が無事にチンワトの橋を渡って, 天国に行け るように守ってくれるのである。それ故, ゾロアスター教徒は, 死後 4 月目の Bāj の 義式で, 死者のためにワユへ供物 drōn を献ずる風習がある。

スラオシャは「忠直」の神霊であり，ラシュヌとアルシュタートはともに「公正」を 自らの性格とし，ミスラは司法神としての機能を有する。それ故，彼等が登場するのは， 死後 4 日目に行われる死者の善・悪業の審判に関係するのが明らかである。またフラワ シは，祖霊としての性格とともに，ゾロアスター教の創造神話によれば，本来的に天国 の住人であった。そこで子孫が死んだ場合は, アフラ・マズダーにとりなして，天国へ 死者の魂を導くものとされる。以上の者たちに比べると, 風神がここに登場するのは, 一見不可解である。しかし, 彼が両界一つまりこの世とあの世一一境に位置付けら れることを考光れば納得がいく。

ゾロアスター教の死後審判は, 丁度この世とあの世の境でなされる。死後 3 日間は死 者の頭の付近にあった魂が，そこから離れて後，天国あるいは地獄へ赴く前になされる のが，死後の審判である。この境は，仏教的に言えば，現世と来世の中間である中陰に あたる。ただン゙ロアスター教では転生を説かないので, 来世は天国（地獄）そのものと 見做される。そしてこの境を, 仏教の三途の渡しと同様な, チンワトの橋で象徴し, そ こで善・悪業の審判がなされるとする。先述の南風と北風は，死者の魂がこのチンワト 橋に向から 4 日目の朝に, 吹いて来るのである。つまり, ここで風は, この世とあの世 と云う, 二つの世界の境に関係している。

二つの世界の境は, 両者の勢力が及ぶ不安定な境遇である。あの世とこの世の場合も 例外でない。『アヴェスタ』では, ワユと共に死神とされた（アストー・）ウィーザー トゥ Vijōatu と, 死者の守護天使であるスラオシャの闘争が述べられている。後の神学 文献になると, 風そのものが善・悪の陣営に分れて, 死者の魂をめぐって争ら。この善 ・悪両ワユの争いは，逆に言えば，風神本来の両義性を証拠立てるるのでもある。つま り結局のところ, 両界の境に位置付けられる中間者的性格, さらにその根底にある両義 性が，風を死者の運命に結びつけるのである。そして一方では死神として恐れられると もに，他方では死者の守護者として祈りの対象になったのである。

上述のスラオシャ, ラシュヌ, アルシュタート, ミスラや善きワユの他にも, 死者の 魂を守護するものと考えられているのが, ウルスラグナである。幻視文学として有名な (46) 中世ペルシア語文献 Ardā wīrāf Nāmag は，主人公がチンワト橋を渡るに際して， 
(47)

ウルスラグナ Wahrām の絶大な加護が有ったと述べている。ウルスラグナは，本来は 勝利を神格化したもので武人の守護神であるが，同時に道祖神として旅人を守る機能が 有った。交通の要地に彼の像を祀ったり，旅の安全を祈ってバフラーム呪を唱えたりす る風習がある。それ故，あの世への旅も，ウルスラグナの守護が考光られて当然である。 さらに道祖神は境の神であり，この点からも，チンワト橋の渡過に際して彼が出現する のに不思議は無い。

『アヴェスタ』ではウルスラグナの変身譚が述べられて拉り，そこに馬が登場する。 一般に死から再生への過程，すなわち中有に打いて動物への変身が行われたとする説が 有るが，ウルスラグナの場合も，それにしたがって解釈することが可能である。する と馬は，現世と来世を媒介する動物となる。ハッサンルーで発見された有翼の馬は， Ghirshman によれば，ペガサスの原形であり，死者をあの世に運ぶものと考えられて いる。この説は, ウルスラグナの変化身としての馬と, 興味ある一致を示す。何故なら, ウルスラグナの変身した馬は，飛来 ājasat vazəmnōすると説かれるからである。

中央アジアの考古学的発堀は, 騎馬民族の間で死者とともに, 馬や馬具を陪葬する風 習が有ったことを教える。そして，この死者と馬の結びつきは，印欧語族においては， 先史時代にまで遡る。この種の死者と馬の結びつきの背景として，先ず考学られるのが， 太陽神の信仰と関連した再生思想である。夕に沈み朝に昇る太陽は死と再生の象徵であ り，エジプトでは，死子再生の穀需であるオシリスがしばしば太陽と同一視されだ り，エジプトでは，死と再生の穀霊であるオシリスがしばしば太陽と同一視された。ま た馬は太陽神の乗り物を運ぶ動物と考学られていたから，再生への願いを通して，死者 と馬が結びつくわけである。しかし，死者と馬を結びつける風習の有るところ，必ずし も太陽神の信仰が顕著に見られるわけではないのも事実である。また馬は，すでに述べ たように，雨神や風神とも密接であるから，この死者と馬の結びつきは，より広い見地 に立って考觉る必要がある。

\section{V. 馬の両義性}

馬も風と同様に，両界の境に位置付けられ，それ故また，両界を媒介する働きがある と考えられていた形跡がある。それを暗示するのが，『アヴェスタ』でしばしば言及さ れる馬上の祭祀である。戦士たらはミスラを馬の背で祭った。また英雄トゥサも，アナ 一ヒターを馬上で祭ったとされる。一般に祭祀は, 人間の世界と神々の世界の境と見做 される場所で行われる例が多い。そして, この様な両界の境として, 山, 川, 海などが 考えられた。古代イラン人の信仰も同様で, 『アヴェスタ』の記述からも，ハラー山頂， ダートヤー川岸, ウォルカシャ海畔等, この証をいくらでも列挙できる。そして, これ らに準じて，馬上の祭祀が行われたのである。つまり，そこは神界と現界の境であり， 
神と人の両者が交流する場と考光られたことになる。

古代イランの三大火の一つであるグシュナスプ火 Âdur Gušnasp は，『ブンダヒシ ニン』の記事によれば，元来は馬上の火であった。すなわち，カイ王朝の八オスラワフ Xusrō が偶像崇拝者を征服する際に，馬上にあって闇を払い光を放っていた聖火が， アスナワント山に祭られたのがその起源であるとする。この聖火は専ら戦士階級の尊崇 をうけ，ササン朝の歴代の王が，帝位継承に際して詣でたと伝えられる。そして，戦闘 に拈ける馬の重要性を理由に, この聖火の意義を解釈するのが普通である。しかし, 前 線にあって軍を導く馬上の火は，また敵と味方の境に位置するものでもある。グシュナ スプ火が，後にアゼルバイジャンに祭られることになったのも，境を守るといった性格 が有ったためと推定できる。この地方は，『アヴェスタ』で不義者が住むとされたワル ナ，すなわちギラーンや，ローマとの紛争が絶えなかったアルメニアに近接している。

以上の椂に馬を境に結びつける信仰は，死後の運命に抢けるこの世とあの世の境にあ っても例外でなく，それ故，馬が死者をこの世からあの世へ運ぶ動物と考学られたので ある。そうであるなら，すでに風に関して述べたと同様の両義性を，馬に関して見出せ るとしても不思議でない。つまり，善・悪を峻別するゾロアスター教にあって，馬は善 ・悪いずれにも関係する，特別な動物であった可能性がある。確かにこの証拠は，『ア ヴェスタ』自体の記事に存在する。

「ティシュタル・ヤシュト」では，白と黒の色の違いこそあれ，善なるヤザタである ティシュトリアも，悪なるダェーワのアパオシャも，ともに馬に変身している。さらに Zāmyazd Yašt には, アンラ・マンユ自身が馬に変身する記事さ兄有る。この変身し た馬に騎乗するのが，タクマ・ルピ Taxma Urupay であるが，彼は，人間とともに， ダェーワや呪師 yātav- や魔女 pairikā- の支配者として知られている。つまりここで は，両義的性格を有する英雄の乗物として 馬が考兄られている。また『アヴェスタ』 に登場する人物には, 馬 aspa-に因む名を有する者が少なくないが, Vištaspa と Arəjataspa, Kərəsāspa と Hitāspa のように. 仇敵同士の関係にある善と悪の両英雄が 共にこの例となる。

上に見られるが如き，『アヴェスタ』に拈ける馬の両義性は，インド・イラン的な基 盤を有するものである。馬 aśva-より派生したとされる,『リグ・ヴェーダ』のアシュ ヴィン双神は, 両数形 aśvinau-で登場する。この点について, 最古の註である Yāska (BC. 32:)）の『ニルクタ』に，興味ある記事が見られる。すなわち，...tatkāvaśvinau. dyāvāprtthivyāvityeke. ahorātrāvityeke. sūryācandramasāvityeke. ……である。 これを訳すと次のようになる。「……人のアシュヴィンとは何者であるか。ある人々 は彼等を天と地であると言う。また他の人々は彼等を昼と夜であると言う。さらに別の 
人々は彼等を太陽と月であると言う。」

「ガーサー」には，『ニルタク』で双者として指示される天と地や太陽と月と並んで， 馬を指示する語を両数形で述べた文がある。すなわち，...kā vātāi dvancmaibyasčā yaogət $\mathrm{a}$ sū... である。これを訳せば，「誰が，風と雲に，駿足の双者を熬いだのか。」 となるが, āsū は distributive dual で，風と雲の各々の乗り物を曳く，一対の輓獣 を指す。輓獣が馬であることは，『アヴェスタ』の他の個所で，この語を馬を修飾する 形容詞として用いる例から知られる。

上記の「ガーサー」の場合，一対で挙げられる両者の各及は，共にアフラ・マズダー の被造物であることを予想して述べられて抢り，善と悪に対立するものではない。しか し，光と闇や覚醒と睡眠といった後のゾロアスター教において相互に対立し，一方は善 に他方は悪になるものも同様の扱い方で述べられている。つまり，後に善と悪に分離す る要素をもつもの，すなわち両義性を有するものが，特にとれとして区別されることな く述ベられている。それ故『ニルクタ』や「ガーサー」の双者（両数形）にも，この種 の両義性を予想できる。またアシュヴィン双神の別名であるナーサティア（Av．Nå̄n-

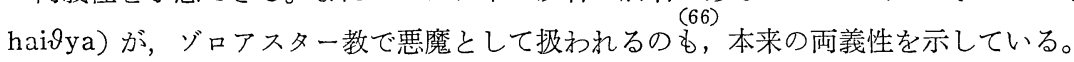

\section{VI. 結 論}

これまでのイラン学では，馬と戦士の特別な関係に言及してはいても，そこから両義 性を問題にするまでには至らなかった。しかし戦士たちに信仰され馬と密接であったミ スラは、『アヴェスタ』で善き者であるとともに悪しき者であると述べられ（67) その両義 性が顕著である。彼の戦神としての性格も，この両義性に関係する。それ故，戦士と馬 の場合も，この両義性を背景にもつことが予想される。そこで民族学的な風と馬の関係 をとントに，『アヴェスタ』における馬の意義を検証すると，境に位置する両義的存在 であるワユと共通の性格が見出せる。

馬の両義性は，善・悪を峻別する二元論を特色とするゾロアスター教にとっては，は なはだ厄介なものであった。同様の性格を有するワユが善と悪に分離し，各々ヤザタと ダエーワのグループに二分された様に，馬の場合も，白と黒の象徴を以て，その両義性 を分離せんとする傾向が見てとれる。またミスラの信仰が，光明神の崇拝を前面に出す ことによりゾロアスター教的に公認されるのにともない，馬と太陽の結びつきが積極的 に主張され，その本来の性格が不明瞭になったのも事実である。しかし，馬の両義性は 完全に忘却されたわけではなく，それ故、ゾロアスター教では聖獣として，馬よりも牛 を重視せざるを得なかった。本来は馬と密接であるべき「ドゥルワースプ・ヤシュト」 (68)

も，また Gōš Yašt の名で呼ばれ，その主人公は牛の魂であるとされた。 


\section{注}

(1) Yt. XIII-10, XIX-69 etc.

（2）Gāソāa はs. XXVIII をもって始まるが，内容的には，Ys. XXIX そ冒頭に位 置させるべき。

(3) I. J. S. Taraporewala, The Divine Songs of Zarathushtra, Bombay, 1951, p. 36 .

(4) $\mathrm{TD}_{2}$, pp. 93-94.

（5）フェルマースレン，小川英雄訳『ミトラス教』山本書店，1973年，79頁。

(6) M. Boyce, A History of Zoroastrianism, Vol. I, Leiden, 1975, p. 82. 参照。

（7）この方面における研究の代表的なものとして，ヤーン・プーヴェル，堀美佐子訳

『馬の神話的機能——印欧語族の宗教に抢ける』,『現代思想』第 4 巻第 6 号, 1976年, 200-214頁がある。

(8) Vol. II, f. 7, New York, 1987.

(9) Yt. X-125.

(10) Ibid. X-102.

（11）Anabasis, IV-5-35（松平千秋訳『アナバシス』筑摩書房，1985年，129頁）。

(12) 「列王紀下」XXIII-11.

（13）Herodotus，I-26（松平千秋訳『歴史』上，岩波文庫，1971年，159頁）。

（14）本来, 太陽神はフワルであり，ミスラと区別される。

（15）Yt. VIII-26ff. (岡田明憲『ゾロアスター教——神々への讃歌』平河出版社, 1982

年, 156頁)。

（16） E．E．クジミナ，林俊雄訳「アジア草原の芸術に和ける二頭の動物の闑争文」, 『ユーラシア』新 1 号, 1983年, 95-105頁。

(17) J. Gonda, Vedic Ritual, Leiden 1980, pp. 134, 225.

（18）この種の代表的なものに，石田英一郎『河童駒引考』，岩波文庫，1994年がある。

（19）井本英一『境界，祭祀空間』平河出版社，1985年，336頁。

（20） C. G. ユング，野村美紀子訳『変容の象徵』筑摩書房，1985年，421頁。

(21) L. A. Waddell, The Buddhism of Tibet or Lamaism, 2nd. London, 1939, p. 412 .

（22）Ｒ．A．スタン著，山口・定方訳『チベットの文化』岩波書店，1971年，参照。

（23）田辺勝美「ウェーショー：クシャン朝のも5一つの風神」, 『古代オリエント博物 館紀要』第13巻, 1992年, 51-93頁。

(24) Yt. XV-46, 54, 57.

(25) Ys. LVII-28.

(26) E. W. Hopkins, Epic Mythology. rep. Delhi, 1974, p. 94.

(27) Bundahišn, $\mathrm{TD}_{2}$, p. 31, 1. 15.

（28）以下の訳は，岡田明憲「アヴェスタ抄訳(-)——日・月・風神の讃歌」，『世界口承 
文芸研究』第 9 巻，1987年，367-383頁。

(29) Ys. XXV-5; Yt. XV-5, 57.

(30) M. N. Dhalla, Zoroastrian Theology, New York, 1914, pp. 132, 172.

(31) Rg, X-137-2.

(32) Hā $\delta \bar{o} x t$ Nask, II-7, 25.

(33) Yt. X-50, Vd. II-5.

(34) Vd. XIX-1.

（35） $\mathrm{TD}_{2}, \quad$ p. 3，1. 5.（伊藤義教「ブンダヒシュン書の序・序章と etymologica Bundahišnicaについて」『西南アジア研究』第 6 巻, 1961年, 7 頁)。

(36) M. Boyce, Zoroastrians-Their Religious Beliefs and Practices, London, 1979, pp. 67ff.

（37）佐藤信夫『新アルメニア史』泰流社，1989年，102-105頁に，原文と日本語訳が ある。

(38) W. Geiger, Leipzig, 1878, S. 35; K. M. JamaspAsa, Wien, 1982, p. 42. (39) Vd. XIX-29.

(40) R. C. Zaehner, The Dawn and Twilight of Zoroastrianism, London, rep. 1975, p. 209.

(41) Aog. 8, (Geiger, S. 23; JamaspAsa, p. 24.)

(42) J. C. Pavry, The Zoroastrian Doctrine of a Future Life, New York, 1929, p. 86.

（43）人間が創造される以前に，フラワシは神や天使と共に天国にあって幸福だった。 しかし，彼等は人間と共に悪と戦らために地上に降下し，人間の死後に再び天上に戻 る途を選択した。

(44) Ys. LVII-25.

(45) Dādistān ì Menōg i Xrad, II-115ff. (West, London, 1871, p. 9)

（46）現在では Wirāf をWirāz とした方が，言語学的にはより正しいが，かなり有 名な書であるため, ここでは昔からの慣用に従う。

(47) AWN. V-3, (Haug-West, Bombay, 1872, p.21; F. Vahman, London, 1986, p. 94)

（48）ビストゥーンのウルスラグナ（ヘラクレス）像も，この例と考えられる。

（49） Yt. XIV-9.（この変身譚の全般に関しては，岡田明憲「古代イランの動物変身」

『象徵図像研究』第 6 巻, 1992年, 5-13頁, 参照。)

（50）井本英一『輪廻の話—ーリエント民俗誌』法政大学出版局，1989年，245頁。

（51） R. ギルシュマン，岡谷公二訳『古代イランの美術 I』, 新潮社, 1966年, 291頁。

(52) M. Lurker, Wörterbuch der Symbolik, Stuttgart, 1983, S. 634.

（53）な拈，この点に関しては Frazer の批判もある。The Golden Bough, abr. ed. 1922, rep. 1960, pp. 505-507. 
(54) Yt. X-11.

(55) Yt. V-53.

(56) $\mathrm{TD}_{2}$, p. 125, 1. 4-8.

(57) H. D. K. Mirza, The Zoroastrian Religion, Bombay, 1977, p. 149.

(58) Yt. V-22; X-68, 97; XIX-26 etc.

(59) Yt. XIX-29.

(60) M. Mayerhofer, Iranisches Personennamebuch, Bd. I, f. 3, Wien, 1979, S. 4 参照。

(61) Nirukta, XII-1. (L. Sarup ed, rep. Delhi, 1967, Pt. III p. 206)

(62) Ys. XLIV-4.

(63) S. Insler, The Gäthās of Zarathustra, Acta Iranica 8, Leiden, 1975, p. 243.

H. Humbach, The Gäthās of Zarathushtra and the Other Old Avestan Text, Heidelberg, 1991, pt. II, p. 150.

(64) Yt. XIII-52; XVII-12.

(65) Ys. XLIV-5.

（66）伊藤義教博士は，日本オリエント学会第35回大会に括いて，「ヤサー・アフー・

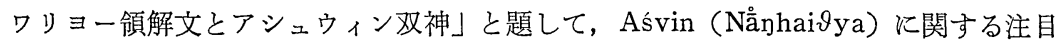
すべき新見解を発表された。本論文では遺憾ながら，この新説に言及できなかった。 (67) Yt. X-29.

（68）インドでは, dhruvāśvakalpa を Áśvina, すなわちアシュヴィンの母の月に行 5, (Gonda, op. cit. p. 426)。 